\title{
The Coat Protein of Cucumber Mosaic Virus Is a Host Range Determinant for Infection of Maize
}

\author{
Ki Hyun Ryu, ${ }^{1}$ Chung-Ho Kim, ${ }^{1}$ and Peter Palukaitis ${ }^{1,2}$ \\ ${ }^{1}$ Department of Plant Pathology, Cornell University, Ithaca, NY 14853, U.S.A.; ${ }^{2}$ Virology Department, Scot- \\ tish Crop Research Institute, Invergowrie, Dundee, DD2 5DA U.K. \\ Accepted 1 February 1998.
}

Infection of maize by the Fny strain of cucumber mosaic virus (CMV) and resistance against infection by the $M$ strain of CMV were mapped to the coat protein gene on RNA 3 of CMV, using biologically active cDNA clones of Fny-CMV RNAs 1, 2, and 3 and RNAs 2 and 3 of M-CMV, as well as chimeras constructed between cDNA clones of M-CMV and Fny-CMV RNA 3. Changes in the coat protein gene of M-CMV RNA 3 at both positions 129 (Leu to Pro) and 162 (Thr to Ala) were required to overcome the resistance against $\mathrm{M-CMV}$ in maize. Resistance to $M$ CMV in maize was correlated with an inability to detect virus accumulation in the inoculated leaves. Since the coat protein of $\mathrm{CMV}$ is involved in virus movement, but not virus replication, the data suggest that the resistance in maize to M-CMV is due to the inability of the M-CMV coat protein to promote the cell-to-cell movement of $\mathrm{CMV}$ in maize.

Additional keywords: cucumovirus, plant virus.

Resistance to plant viruses occurs at several levels: activation of a hypersensitive response, which in many cases also prevents further infection; inhibition of virus replication; inhibition of cell-to-cell (local) movement; and inhibition of long distance (systemic) movement (reviewed by Ponz and Bruening 1986; Fraser 1990). The latter two are the most common forms of resistance (reviewed by Fraser 1986). Several viral gene products are involved both in promoting local and systemic movement, and in inducing resistance responses. Gene products involved in the replication of several viruses have been implicated in the systemic movement of those viruses (Traynor et al. 1991; Gal-On et al. 1994; Ding et al. 1995c; Chen et al. 1996; Derrick et al. 1997; Nicolas et al. 1997). The movement protein (MP) of tomato mosaic tobamovirus (ToMV) is the elicitor of two resistance genes in tomato that prevent the local movement of ToMV (Meshi et al. 1989; Weber et al. 1993). The coat protein (CP) of tobamoviruses is involved in promoting their systemic movement via the phloem (Hilf and Dawson 1993; Ding et al. 1996). In some

Corresponding author: P. Palukaitis; Telephone: 44-1382/568523; Fax: 44-1382/522426; E-mail ppaluk@ scri.sari.ac.uk

Present address of C.-H. Kim: Department of Food and Nutrition, Seowan University, 231, Mochung-Dong, Chongju-City Chung Chong Buk-Do 360-742, Republic of Korea. cases, the $\mathrm{CP}$ is the elicitor of either a hypersensitive response (Knorr and Dawson 1988; Santa Cruz and Baulcombe 1993; Berzal-Herranz et al. 1995; Suzuki et al. 1995) or a general inhibitor of viral RNA replication (Köhm et al. 1993). For some viruses, the $\mathrm{CP}$ is required for cell-to-cell movement (Wellink and van Kammen 1989; Chapman et al. 1992; Laakso and Heaton 1993; Dolja et al. 1994; Schmitz and Rao 1996). In the case of cucumber mosaic cucumovirus (CMV), the CP is required for local movement (Suzuki et al. 1991), and also for systemic movement (Taliansky and García-Arenal 1995), and specific regions of the CP of CMV also have been delimited that affect systemic infection by CMV in zucchini squash (Shintaku and Palukaitis 1990).

CMV is a positive-sense, RNA virus with a divided genome, expressing five proteins from the three genomic and two subgenomic RNAs (reviewed by Palukaitis et al. 1992; Ding et al. 1994). The numerous strains of CMV have a collective host range of over 885 species in 65 families, including monocotyledonous as well as dicotyledonous plants (Douine et al. 1979). For example, some strains of CMV are able to infect maize (Douine et al. 1979; Wahyuni et al. 1992). Little is known about natural infection of maize by CMV. It is considered a "minor virus disease" of maize (Schurtleff 1980; Boothroyd 1981). A number of maize cultivars appear susceptible to CMV. Two that have been used for molecular studies are cv. Golden cross Bantam (Marchoux et al. 1975; Waterworth et al. 1979; Jacquemond and Leroux 1982) and cv. Iochief (Wahyuni et al. 1992). Based on mapping studies involving pseudorecombinants formed between restricted and resistance-breaking strains, both RNA 2 (Rao and Francki 1982) and RNA 3 (Marchoux et al. 1975) have been implicated as being involved in resistance breakage in maize. Since RNAs 1 and 2 of CMV encode proteins involved in the replication of the viral genome (Nitta et al. 1988; Hayes and Buck 1990) and also play some role in virus movement (Gal-On et al. 1994; Ding et al. 1995b), and RNA 3 encodes the MP (Kaplan et al. 1995) and CP (Habili and Francki 1974), it appears that resistance to $\mathrm{CMV}$ in maize may occur at several levels, as has been observed for ToMV in various tomato cultivars (Meshi et al. 1988, 1989; Weber et al. 1993) and potato virus $\mathrm{X}$ potexvirus (PVX) in various potato cultivars (Santa Cruz and Baulcombe 1993; Goulden et al. 1993). In this paper, we identify the viral sequences involved in resistance in maize to the M-strain of CMV and analyze the nature of the mechanism of this resistance. 


\section{RESULTS AND DISCUSSION}

\section{Delimitation of resistance breakage to CMV RNA 3.}

The M strain of CMV was reported not to infect maize (Rao and Francki 1982; Wahyuni et al. 1992), while the Fny strain of CMV did (Wahyuni et al. 1992). To delimit which CMV RNA(s) affect this phenotype, various composite viruses were generated and were inoculated to the maize cv. Iochief used by Wahyuni et al. (1992). Biologically active cDNA clones of each RNA of Fny-CMV were used as templates for generating RNA transcripts corresponding to FnyCMV RNA 1, RNA 2, and RNA 3. These were added individually to the M-CMV RNAs and were used to inoculate tobacco, a systemic host for both Fny-CMV and M-CMV. The concentrations of Fny-CMV and M-CMV in the tobacco plants were similar (Perry et al. 1998; data not shown). Sap from infected tobacco was inoculated to maize seedlings. In general, only those tobacco plants inoculated with M-CMV RNAs 1 to 3 and Fny-CMV RNA 3 yielded virus capable of infecting maize (Table 1). Back inoculation from systemically infected maize leaves to tobacco plants resulted in infection of the tobacco plants, producing the severe yellow chlorosis characteristic of infection of tobacco by M-CMV (data not presented) or, more specifically, the M-CMV CP gene, which is known to be responsible for the induction of this phenotype (Shintaku et al. 1992).

Previously, we constructed a biologically active cDNA clone of M-CMV RNA 3, and we demonstrated that several phenotypes associated with M-CMV could be delimited to the CP gene of this strain (Shintaku and Palukaitis 1990; Shintaku et al. 1992; Perry et al. 1994). Transcripts representing MCMV RNA 3 were combined with transcripts of the cDNA clones of Fny-CMV RNAs 1 plus 2 (F1F2M3) and were passaged first through tobacco prior to inoculation of maize. (We have not been able to establish infection of maize directly with any CMV RNA transcripts.) The maize seedlings did not become infected, either here (Table 1; Fig. 1) or in subsequent experiments (Figs. 2 and 3). By contrast, transcripts of the cDNA clones of Fny-CMV RNAs 1, 2, and 3 passaged through tobacco first could infect maize (Table 1; Fig. 1), while transcripts of cDNA clones of Fny-CMV RNAs 1 plus 3 and M-CMV RNA 2 (F1M2F3) could infect maize (Table 1). Thus, the inability of M-CMV to infect maize appears to be associated with RNA 3. Moreover, since M-CMV RNA 3 could not support infection of maize while Fny-CMV RNA 3 could, the ability of M-CMV RNAs 1 to 3 plus Fny-CMV RNA 3 to infect maize and induce typical M-CMV symptoms on back inoculation to tobacco indicates that both RNAs 3 can be supported simultaneously in both hosts.

The initial observation that the inability of M-CMV to infect maize mapped to RNA 2 (Rao and Francki 1982) could not be substantiated here. RNA transcribed from a full-length cDNA clone of M-CMV RNA 2 combined with transcripts of Fny-CMV RNAs 1 and 3 was able to infect maize (Table 1). However, the original observations were made with pseudorecombinants between M-CMV and K-CMV (Rao and Francki 1982). Unfortunately, biologically active cDNA clones of all three K-CMV RNAs and M-CMV RNA 1 were not available. Moreover, the pseudorecombinant viruses constructed by Rao and Francki (1982) were no longer viable. Thus, it was not possible to make direct comparisons.
Localization of resistance breakage to within the CP gene.

A series of reciprocal chimeras was created previously between the cDNA clones of Fny-CMV RNA 3 and M-CMV RNA 3 to map other phenotypes delimited to M-CMV RNA 3 (Shintaku et al. 1992; Perry et al. 1994). These chimeric cDNA clones were transcribed and the RNA transcripts were combined with transcripts of the cDNA clones of Fny-CMV RNAs 1 plus 2 and inoculated to tobacco. Since the virions of M-CMV required a different purification scheme than FnyCMV (Mossop et al. 1976), and the particles were not as stable upon storage, we routinely used sap from recently infected tobacco plants as the inocula for the maize plants. The titers of F1F2M3-CMV and various RNA 3 chimeras were shown to be similar at 10 to 12 days post inoculation (Perry et al. 1998; data not shown), at which time the infected tobacco plants were used as the source of inoculum.

Figure 2 shows the infectivity data for the various chimeric RNAs 3. Chimeras in which part or all of the 3a (MP) gene came from Fny-CMV, but the CP gene came from M-CMV (FMNhe and FMSal) were unable to infect maize, whereas the reciprocal chimeras (MFNhe and MFSal) were able to infect maize. (There are no sequence differences in the CP gene upstream of the SalI site.) The infectivity data from chimeras splitting the CP gene in almost equal halves (FMHin and MFHin) showed that the sequences responsible for restriction and resistance breakage mapped downstream of the HindIII site (Fig. 2). The infectivity of chimeras involving exchange of the $\mathrm{C}$ terminus of the $\mathrm{CP}$ gene and $3^{\prime}$ nontranslated region (FMXho and MFXho) demonstrated that the viral sequences involved in resistance or resistance breakage were localized within the CP gene, between the HindIII and XhoI sites (Fig. 2). A further attempt to subdivide this region by the use of chimeras with sequences exchanged at the $C f r 10 \mathrm{I}$ site yielded ambiguous results. Most of the plants remained uninfected, although a few plants did show virus replication without the production of symptoms for the chimera FMFCfr (Fig. 2). In the latter infected plants, the level of accumulated virus was about 10-fold lower than in plants infected by other chimeras (data not presented), which showed visible symptoms of virus replication and movement. Thus, it appears that sequences between both the HindIII site and the Cfr10I site as well as between the $C f r 10 \mathrm{I}$ site and the XhoI site are involved in resistance breakage, and in most inoculated plants, changes in both regions are required to break the resistance.

Table 1. Infectivity on maize of cucumber mosaic virus (CMV)-infected tobacco extracts

\begin{tabular}{lc}
\hline RNA inocula $^{\mathbf{a}}$ & Infectivity $^{\mathbf{b}}$ \\
\hline M1M2M3 + F1 & $0 / 10$ \\
M1M2M3 + F2 & $1 / 10 ; 0 / 5$ \\
M1M2M3 + F3 & $2 / 10 ; 3 / 3$ \\
F1F2M3 & $0 / 5$ \\
F1M2F3 & $6 / 10$ \\
F1M2M3 & $0 / 5$ \\
F1F2F3 & $10 / 10$ \\
\hline
\end{tabular}

a Inocula on tobacco consisted of mixed RNAs or reconstructed pseudorecombinants, as indicated in Materials and Methods. Individual RNAs of CMV strains Fny or $\mathrm{M}$ are designated as 1, 2, or 3; e.g., F1F2M3 contains RNAs 1 plus 2 of Fny-CMV and RNA 3 of M-CMV.

${ }^{b}$ Number of maize plants infected over number inoculated. Data from two separate experiments are shown for M1M2M3 + F2 and M1M2M3 + F3. Data reflect infectivity ascertained by symptoms and verified by dot blot hybridization analyses of inoculated and noninoculated leaves. 
Localization of specific CP sequences involved in resistance breakage in maize.

There are 13 nucleotide differences (Shintaku et al. 1992) and seven amino acid differences between the $\mathrm{CP}$ genes of $\mathrm{M}$ CMV and Fny-CMV (Fig. 3). Between the HindIII and XhoI sites, there are seven nucleotide differences in M-CMV RNA 3 versus Fny-CMV RNA 3 (not shown). One of these, encod-
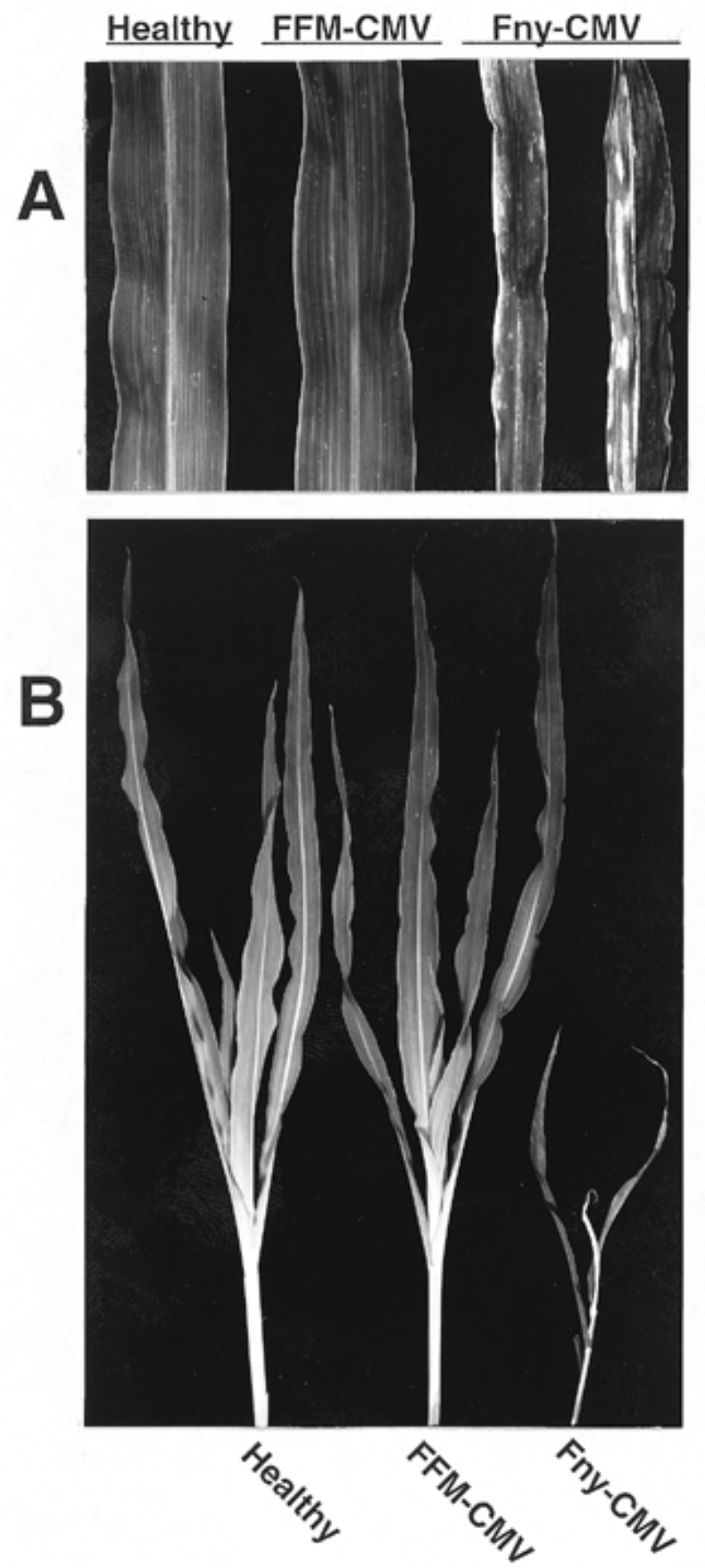

Fig. 1. Pathology of cucumber mosaic virus (CMV) on maize. Maize leaves (A) and plants (B) inoculated with either Fny-CMV or the pseudorecombinant virus F1F2M3-CMV (FFM-CMV) compared with mock inoculated maize (Hea. or Healthy). The foliar symptoms induced by Fny-CMV varied from chlorotic streaks (left leaf in A) to necrotic streaks (right leaf in $\mathbf{A}$ ), which sometimes led to systemic necrosis. ing an amino acid change (position 129), is between the HindIII site and the Cfr10I site, and six are between the Cfr10I site and the XhoI site (Shintaku et al. 1992). The latter include three amino acid changes (Fig. 3; positions 162, 168, and 187) and three silent mutations (Shintaku et al. 1992).

A series of mutants was constructed previously in the cDNA clone of M-CMV RNA 3 to alter the sequences encoding the amino acids at positions 129, 162, and 168 of the M-CMV CP to those found in Fny-CMV (Shintaku et al. 1992; Perry et al. 1994). These positions contain radical amino acid substitutions, and all three positions were implicated in affecting the transmission of CMV by the aphid vector of CMV, Aphis gossypii (Perry et al. 1994). Two additional mutants (M-162A and M-168Y; Fig. 3) were constructed for this study.

Maize plants were inoculated with sap from tobacco infected with transcripts of the above mutant RNAs 3 and FnyCMV RNAs 1 plus 2 . The infectivity results were confirmed by dot blot hybridization (not shown), since the symptoms induced by the mutants generally were not as severe as those induced by Fny-CMV. Inoculation of maize by CMV containing any of the single mutants (M-129P, M-162A, or M$168 \mathrm{Y}$ ) yielded no infected plants (Figs. 3 and 4), while CMV containing either the double mutant M-129P/162A or the triple mutant M-129P/162A/168Y infected nearly all of the plants inoculated (Fig. 3). Virus containing the double mutant M-

\section{RNA 3 Construct}

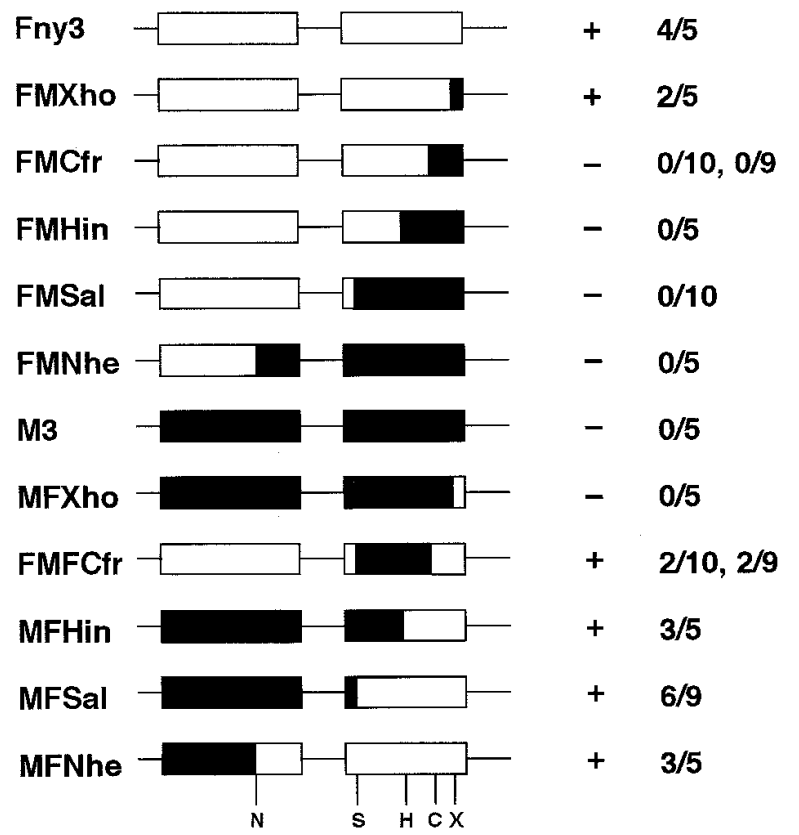

Fig. 2. Infectivity of reconstructed cucumber mosaic virus (CMV) on maize. The CMV inocula contained RNAs 1 and 2 from Fny-CMV and RNA 3 derived from Fny-CMV (Fny 3), M-CMV (M3) or chimeras formed between cDNA cloned of Fny-CMV RNA 3 (open rectangles) and M-CMV RNA 3 (filled rectangles). using the restriction sites NheI (N), SalI (S), HindIII (H), Cfr10I (C), or XhoI (X). The movement protein (MP; left) and coat protein (CP; right) genes on RNA 3 are depicted as rectangles. The infectivity of virus containing the wild-type or chimeric RNAs 3 is indicated by "+" or "-" with the number of infected plants shown over the number of inoculated plants. Infectivity was assessed initially by symptoms, and verified by dot blot hybridization. 
129P/168Y did not infect any of the plants inoculated (Fig. 3). The double mutant M-162A/168Y was not constructed, since the FMFCfr chimera also contained the same substitutions, and this virus infected only a low proportion of the inoculated plants (Fig. 2). The ability of the virus containing the double mutant M-129P/162A to infect all of the inoculated maize seedlings, and the inability of inocula containing either the double mutant M-129P/168Y or the three individual mutants to do so (Fig. 3), indicate that either the amino acids or the RNA sequences corresponding to both amino acid positions 129 and 162 are involved in the resistancebreaking phenotype.

\section{Analysis of the resistance expression.}

Those mutant viruses that were able to infect maize accumulated to levels similar to that of Fny-CMV in the systemically infected maize leaves (Fig. 4). Thus, the differences in pathology between these mutants and Fny-CMV were not due to differences in accumulation. Those mutants that did not infect maize systemically also showed no detectable accumula- tion of CMV in the inoculated leaves (Fig. 4). Thus, it appears that F1F2M3-CMV either cannot replicate or cannot move within the inoculated leaf.

The localization of replication functions to RNAs 1 and 2 of CMV (Nitta et al. 1988; Hayes and Buck 1990), and the ability of M-CMV plus Fny-CMV RNA 3 to infect maize argues against an inhibition of replication. However, direct proof of such requires a comparison of the replication efficiencies in maize protoplasts. Attempts to prepare (Fromm et al. 1987), inoculate (Samac et al. 1983), and maintain protoplasts from leaves of the maize cv. Iochief generally have been unsuccessful. Thus, we cannot eliminate the possibility that some aspect of the resistance mechanism occurs at the level of some limited inhibition of replication.

\section{Possible mechanisms of resistance.}

The resistance of maize to infection by M-CMV could be operating by any of several mechanisms: (i) The M-CMV CP may be unable to interact with some host component to facilitate the cell-to-cell movement of CMV. Genetic experi-

RNA 3

Amino Acid Positions

\section{Infection of maize}

\section{Construct}

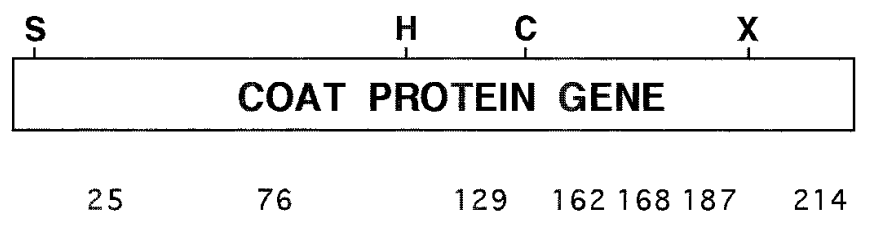

Fny-CMV

M-CMV

M-129P

M-162A

M-168Y

$M-129 P / 162 A$

M-129P/168Y

$M-129 P / 162 A / 168 Y$

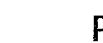

P

K

P

A

L $\quad \mathrm{T}$

$\mathrm{R}$

\begin{tabular}{llllllll}
$S$ & $R$ & $L$ & $T$ & $C$ & $I$ & $R$ \\
\hline & & & & & & & \\
$S$ & $R$ & & $P$ & $T$ & $C$ & $I$ & $R$ \\
\hline
\end{tabular}

L A C I

R

0/16,

0/16

\begin{tabular}{|c|c|c|c|c|c|c|}
\hline $\mathrm{S}$ & $\mathrm{R}$ & $L$ & $A$ & C & I & $\mathrm{R}$ \\
\hline S & $\mathrm{R}$ & $L$ & $\mathrm{~T}$ & $Y$ & 1 & $\mathrm{R}$ \\
\hline
\end{tabular}

0/16,

$0 / 16$
18/18, $2 / 2$

0/16, $\quad 0 / 16$

17/18,

2/2

Fig. 3. Infectivity of wild-type and coat protein (CP) mutant cucumber mosaic virus (CMV) on maize. The CMV inocula contained RNAs 1 and 2 from Fny-CMV and RNA 3 derived from Fny-CMV, M-CMV, or mutants of M-CMV created by site-directed mutagenesis of the nucleotides encoding amino acids 129, 162, and 168 of the M-CMV CP gene to the corresponding codons of the Fny-CMV CP gene. The infectivity (on the right) of CMV containing the indicated RNA 3 is given as the number of plants infected over the number of maize seedlings inoculated. Infectivity was verified by dot blot hybridization. The restriction sites indicated by $\mathrm{S}, \mathrm{H}, \mathrm{C}$, and $\mathrm{X}$ as in Figure 2. 
ments have demonstrated the requirement of the CP for cellto-cell movement (Canto et al. 1997); however, microinjection experiments involving the 3 a protein and RNA have demonstrated that the 3 a protein alone can potentiate the movement of RNA (Ding et al. 1995a). This contradiction has not been resolved, but may relate to either a requirement for $\mathrm{CP}$ for movement into or out of certain cell types, or differences arising from the techniques used (i.e., infection versus microinjection). (ii) The M-CMV CP may elicit a host response or interact with a host protein while the Fny-CMV CP does not. This seems unlikely since such a putative, inhibitory response or interaction did not occur with the M-CMV CP in the presence of the Fny-CMV CP, as demonstrated in the experiments involving M-CMV and Fny-CMV RNA 3 (Table 1). This is by contrast to the mechanism of resistance of the $R x$ gene in potato against most strains of PVX, where the CP gene elicits a response that affects the replication of even unrelated viruses (Köhm et al. 1993). (iii) The Fny-CMV CP may suppress a response that normally occurs on infection, and the M-CMV $\mathrm{CP}$ fails to do so. The data presented here do not allow for a discrimination between mechanisms (i) and (iii).

RNA 3 of CMV was implicated in the restriction of infection in maize with two other pairs of strains of CMV: the infectivity of pseudorecombinants between D-CMV and RCMV indicated that RNA 3 of D-CMV conditioned for resistance in maize (Marchoux et al. 1975), and pseudorecombinants formed between Fny-CMV and LS-CMV were used to demonstrate that resistance to infection of maize by LS-CMV (Wahyuni et al. 1992) mapped to RNA 3 (Zhang and Palukaitis 1993). However, in the latter case resistance breakage mapped to the $3 \mathrm{a}$ gene and not to the $\mathrm{CP}$ gene. Thus, a

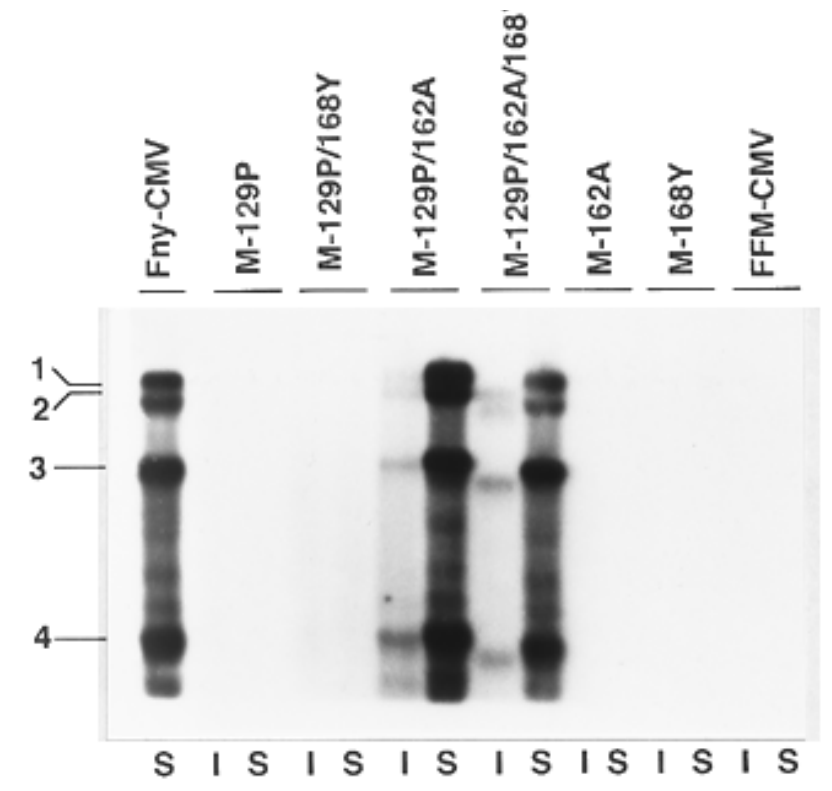

Fig. 4. Analysis of cucumber mosaic virus (CMV) RNA accumulation in inoculated maize plants. CMV RNA accumulation was detected by Northern (RNA) blot hybridization in the inoculated leaf (I) and in an upper, noninoculated or systemic leaf $(S)$ of maize plants inoculated with Fny-CMV, the pseudorecombinant virus F1F2M3-CMV (FFMCMV) or virus containing various M-CMV CP mutants (see Figure 3 caption), 2 weeks post inoculation. Migration of the four CMV RNAs is indicated on the left. similar phenotype can map to different viral genes involved in the movement of CMV, and it seems likely that different plant genes are involved in the different mechanisms of resistance to $\mathrm{CMV}$.

The ability of a few plants to become infected with one of the chimeras (FMFCfr in Figure 2) and one of the pseudorecombinants (M1M2M3 + F2 in Table 1) suggests there may be some threshold to the establishment of a systemic infection. The failure of the progeny virus from such infections to infect maize upon subsequent inoculation indicates that further mutation at either one of the two sites identified here or some other site in the genome is unlikely to be responsible for this occasional resistance breakage. Rather, this might indicate possible interactions involving several host gene products. Mutation at one or more of four positions within the MP gene of brome mosaic virus also resulted in a variable frequency of systemic infection in cowpea plants, depending upon both the nature of the mutation(s) and the cultivar of cowpea (DeJong et al. 1995). Alternatively, since several sites in the CP genes of PVX and TMV were shown to affect the expression of resistance by the $N x$ and $N^{\prime}$ genes, respectively (Culver and Dawson 1989; Santa Cruz and Baulcombe 1993), it seems more likely that structural changes in the CP of M-CMV determine the extent of interaction with some maize gene product(s). The amino acids at positions 129 and 162 have already been implicated in other interactions (Shintaku and Palukaitis 1990; Perry et al. 1994). The recent three-dimensional structural analysis of the CMV particle predicts that amino acid 129 is on the surface of the virus particle, while amino acid 162 is inside the particle (Wikoff et al. 1997). Nevertheless, to what extent changes at one locus affect the overall structure of the virus and how these structural changes may affect interactions with plants and insects remain to be established.

\section{MATERIALS AND METHODS}

Plants, virus inoculation, and plant maintenance.

Tobacco (Nicotiana tabacum cv. Samsun NN) plants were inoculated at the four- to six-leaf stage as previously described (Rizzo and Palukaitis 1990). The inocula were sap from infected plants, purified virus, or RNA transcripts generated from cDNA clones (Zhang et al. 1994). Fny-CMV (Rizzo and Palukaitis 1990), and M-CMV (Mossop et al. 1976) were stored as frozen viral RNAs. The cDNA clones were derived from Fny-CMV RNAs 1 to 3 (Rizzo and Palukaitis 1990), M-CMV RNA 2 (see below), M-CMV RNA 3 (Shintaku et al. 1992), Fny-/M-CMV RNA 3 chimeras (Shintaku et al. 1992), or a series of M-CMV RNA 3 CP mutants (Perry et al. 1994, and below). Maize (Zea mays cv. Iochief) plants were inoculated at the two- to four-leaf stage with sap from CMV-infected tobacco plants, 10 to 12 days post inoculation. Inoculated plants were maintained in environmentally controlled growth chambers at 25 to $28^{\circ} \mathrm{C}$ with a $14 \mathrm{~h}$ light/ $10 \mathrm{~h}$ dark cycle.

\section{RNA extraction and analysis.}

Total RNAs were extracted from infected maize leaves, either by the method of Palukaitis et al. (1985), or as described by Kaplan et al. (1995). RNAs extracted by the former method were analyzed by dot blot hybridization (Palukaitis et al. 1985), while RNAs extracted by the latter method were ana- 
lyzed by Northern (RNA) blot hybridization, as described previously (Kaplan et al. 1995). In both cases, the ${ }^{32} \mathrm{P}$-labeled RNA probe was complementary to the 3' 200 nucleotides of Fny-CMV RNA 3 (Gal-On et al. 1994). The 3' 200 nucleotides of Fny-CMV RNA 3 and M-CMV RNA 3 are identical in sequence.

\section{Generation of pMCMV2 and of pMCMV3 mutants.}

A full-length cDNA clone of M-CMV RNA 2 was generated with reverse transcription and the polymerase chain reaction (PCR), to produce two half-length cDNA molecules that were then combined by strand-overlap PCR (Sambrook et al. 1989). The primers used to generate the half-length cDNA molecules were as described by Hellwald and Palukaitis (1994). The mutants of the CP gene in pMCMV3 not previously described by Perry et al. (1994) were M-162Y and M168 . Both mutants were prepared by site-directed mutagenesis, using the two-step PCR procedure of Higuchi et al. (1988) as in Perry et al. (1994), with a subclone of pMCMV3 rather than a subclone of the M-129 mutant of pMCMV3 (used in Perry et al. 1994). The mutated sequences were characterized by sequence analysis, after mutagenesis, after reconstruction of the full-length mutated pMCMV3, and from progeny RNA extracted from infected tobacco plants, as described by Perry et al. (1994).

\section{ACKNOWLEDGMENTS}

This work was supported in part by grant no. DE-FG02-86ER13505 from the U.S. Department of Energy and by a grant-in-aid from the Scottish Office Agriculture, Environment, and Fisheries Department.

\section{LITERATURE CITED}

Berzal-Herranz, A., de la Cruz, A., Tenllado, F., Díaz-Ruíz, J. R., López, L., Sanz, A. I., Vaquero, C., Serra, M. T., and García-Luque, I. 1995. The Capsicum $\mathrm{L}^{3}$ gene-mediated resistance against the tobamoviruses is elicited by the coat protein. Virology 209:498-505.

Boothroyd, C. W. 1981. Virus diseases of sweet corn. Pages 103-109 in: Viruses and viruslike diseases of maize in the United States. Southern Coop. Ser. Bull. 247. D. T. Gordon, J. K. Knoke, and G. E. Scott, eds. Ohio Agricultural Research and Development Center, Wooster, $\mathrm{OH}$.

Canto, T., Prior, D. A. M., Hellwald, K.-H., Oparka, K. J., and Palukaitis, P. 1997. Characterization of cucumber mosaic virus IV. Movement protein and coat protein are both essential for cell-to-cell movement of cucumber mosaic virus. Virology 237:237-248.

Chapman, S., Hills, G., Watts, J., and Baulcombe, D. 1992. Mutational analysis of the coat protein gene of potato virus X: Effects on virion morphology and viral pathogenicity. Virology 191:223-230.

Chen, J., Watanabe, Y., Sako, N., Ohshima, K., and Okada, Y. 1996. Mapping of host range restriction of the rakkyo strain of tobacco mosaic virus in Nicotiana tabacum cv. Bright Yellow. Virology 226:198209.

Culver, J. N., and Dawson, W. O. 1989. Point mutations in the coat protein gene of tobacco mosaic virus induce hypersensitivity in Nicotiana sylvestris. Mol. Plant-Microbe Interact. 2:209-213.

DeJong, W., Chu, A., and Ahlquist, P. 1995. Coding changes in the cellto-cell movement gene can extend the host range of brome mosaic virus systemic infection. Virology 214:464-474.

Derrick, P. M., Carter, S. A., and Nelson, R. S. 1997. Mutation of the tobacco mosaic virus tobamovirus 126- and 183-kDa proteins: Effects on phloem-dependent virus accumulation and synthesis of viral proteins. Mol. Plant-Microbe Interact. 10:589-596.

Ding, B., Li, Q., Nguyen, L., Palukaitis, P., and Lucas, W. J. 1995a. Cucumber mosaic virus 3 a protein potentiates cell-to-cell trafficking of CMV RNA in tobacco plants. Virology 207:345-353.

Ding, S.-W., Anderson, B., Haase, H., and Symons, R. H. 1994. New overlapping gene encoded by the cucumber mosaic virus genome. Virology 198:593-601.

Ding, S.-W., Li, W.-X., and Symons, R. H. 1995b. A novel naturally occurring hybrid gene encoded by a plant RNA virus facilitates long distance virus movement. EMBO J. 14:5762-5772.

Ding, X., Shintaku, M. H., Carter, S. A., and Nelson, R. S. 1996. Invasion of minor veins of tobacco leaves inoculated with tobacco mosaic virus mutants defective in phloem-dependent movement. Proc. Natl. Acad. Sci. USA 93:11155-11160.

Ding, X.-S., Shintaku, M. H., Arnold, S. A., and Nelson, R. S. 1995c. Accumulation of mild and severe strains of tobacco mosaic virus in minor veins of tobacco. Mol. Plant-Microbe Interact. 8:32-40.

Dolja, V. V., Haldeman, R., Robertson, N. L., Dougherty, W. G., and Carrington, J. C. 1994. Distinct functions of capsid protein in assembly and movement of tobacco etch potyvirus in plants. EMBO J. 13: 1482-1491.

Douine, L., Quiot, J. B., Marchoux, G., and Archange, P. 1979. Recensement de espèces végétales sensibles au virus de la mosaïque du concombre (CMV). Étude bibliographique. Ann. Phytopathol. 11: 439-475.

Fraser, R. S. S. 1986. Genes for resistance to plant viruses. CRC Crit. Rev. Plant Sci. 3:257-294.

Fraser, R. S. S. 1990. The genetics of resistance to plant viruses. Annu. Rev. Phytopathol. 28:179-200.

Fromm, M., Callis, J., Taylor, L. P., and Walbot, V. 1987. Electroporation of DNA and RNA into plant protoplasts. Methods Enzymol. 153:351-366

Gal-On, A., Kaplan, I., Roossinck, M. J., and Palukaitis, P. 1994. The kinetics of infection of zucchini squash by cucumber mosaic virus indicate a function for RNA 1 in virus movement. Virology 205:280289

Goulden, M. G., Köhm, B. A., Santa Cruz, S., Kavanagh, T. A., and Baulcombe, D. C. 1993. A feature of the coat protein of potato virus $\mathrm{X}$ affects both induced virus resistance in potato and viral fitness. Virology 197:293-302.

Habili, N., and Francki, R. I. B. 1974. Comparative studies on tomato aspermy and cucumber mosaic viruses. III. Further studies on relationship and construction of a virus from parts of the two viral genomes. Virology 61:443-449.

Hayes, R. J., and Buck, K. W. 1990. Complete replication of a eukaryotic virus RNA in vitro by a purified RNA-dependent RNA polymerase. Cell 63: 363-368.

Hellwald, K.-H., and Palukaitis, P. 1994. Nucleotide sequence and infectivity of cucumber mosaic virus (strain K) RNA 2 involved in breakage of replicase-mediated resistance. J. Gen Virol. 75:21212125.

Higuchi, R., Krummel, B., and Saiki, R. K. 1988. A general method of in vitro preparation and specific mutagenesis of DNA fragments: Study of protein and DNA interactions. Nucleic Acids Res. 16:73517367.

Hilf, M. E., and Dawson, W. O. 1993. The tobamovirus capsid protein functions as a host-specific determinant of long-distance movement. Virology 193:106-114.

Jacquemond, M., and Leroux, J.-P. 1982. L'ARN satellite du virus de la mosaïquc du concombre II. Étude de la relation virus-ARN satellite chez divers hôtes. Agronomie 2:55-62.

Kaplan, I. B., Shintaku, M. H., Li, Q., Zhang, L., Marsh, L. E., and Palukaitis, P. 1995. Complementation of virus movement in transgenic tobacco expressing the cucumber mosaic virus 3 a gene. Virology 209:188-199.

Knorr, D. A., and Dawson, W. O. 1988. A point mutation in the tobacco mosaic virus capsid protein gene induces hypersensitivity in Nicotiana sylvestris. Proc. Natl. Acad. Sci. USA 85:170-174.

Köhm, B. A., Goulden, M. G., Gilbert, J. E., Kavanagh, T. A., and Baulcombe, D. C. 1993. A potato virus X resistance gene mediates an induced, nonspecific resistance in protoplasts. Plant Cell 5:913-920.

Laakso, M. M., and Heaton, L. A. 1993. Asp $\rightarrow$ Asn substitutions in the putative calcium-binding site of the turnip crinkle virus coat protein affect virus movement in plants. Virology 197:774-777.

Marchoux, G., Marrou, J., Devergne, J. C., Quiot, J. B., Douine, L., and Lot, H. 1975. Cucumber mosaic virus hybrids constructed by exchanging RNA components. Meded. Fac. Landbouwwet. Rijksuniv. Gent 40:59-72.

Meshi, T., Motoyoshi, F., Adachi, A., Watanabe, Y., Takamatsu, N., and 
Okada, Y. 1988. Two concomitant base substitutions in the putative replicase genes of tobacco mosaic virus confer the ability to overcome the effects of a tomato resistance gene Tm-1. EMBO J. 7:1575-1581.

Meshi, T., Motoyoshi, F., Maeda, T., Yoshiwaka, S., Watanabe, H., and Okada, Y. 1989. Mutations in the tobacco mosaic virus $30-\mathrm{kD}$ protein gene overcome Tm-2 resistance in tomato. Plant Cell 1:515-522.

Mossop, D. W., Francki, R. I. B., and Grivell, C. J. 1976. Comparative studies on tomato aspermy and cucumber mosaic viruses. V. Purification and properties of a cucumber mosaic virus inducing severe chlorosis. Virology 74:544-546.

Nicolas, O., Dunnington, S. W., Gotow, L. F., Pirone, T. P., and Hellmann, G. M. 1997. Variations in the VPg protein allow a potyvirus to overcome $v a$ gene resistance in tobacco. Virology 237:452-459.

Nitta, N., Takanami, Y., Kuwata, S., and Kubo, S. 1988. Inoculation with RNAs 1 and 2 of cucumber mosaic virus induces viral RNA replicase activity in tobacco mesophyll protoplasts. J. Gen. Virol. 69:26952700.

Palukaitis, P., Cotts, S., and Zaitlin, M. 1985. Detection and identification of viroids and viral nucleic acids by 'dot-blot' hybridization. Acta Hortic. 164:109-118.

Palukaitis, P., Roossinck, M. J., Dietzgen, R. G., and Francki, R. I. B. 1992. Cucumber mosaic virus. Adv. Virus Res. 41:281-348.

Perry, K. L., Zhang, L., and Palukaitis, P. 1998. Amino acid changes in the coat protein of cucumber mosaic virus differentially affect transmission by the aphids Myzus persicae and Aphis gossypii. Virology 242:204-210

Perry, K. L., Zhang, L., Shintaku, M. H., and Palukaitis, P. 1994. Mapping determinants in cucumber mosaic virus for transmission by Aphis gossypii. Virology 205:591-595.

Ponz, F., and Bruening, G. 1986. Mechanisms of resistance to plant viruses. Annu. Rev. Phytopathol. 24:355-381.

Rao, A. L. N., and Francki, R. I. B. 1982. Distribution of determinants for symptom production and host range on the three RNA components of cucumber mosaic virus. J. Gen. Virol. 61:197-205.

Rizzo, T. M., and Palukaitis, P. 1990. Construction of full-length cDNA clones of cucumber mosaic virus RNAs 1, 2 and 3: Generation of infectious transcripts. Mol. Gen. Genet. 222:249-256.

Samac, D. A., Nelson, S. E., and Loesch-Fries, L. S. 1983. Virus protein synthesis in alfalfa mosaic virus infected alfalfa protoplasts. Virology 131:455-462.

Sambrook, J., Fritsch, E. F., and Maniatis, T. A. 1989. Molecular Cloning. A Laboratory Manual. 2nd ed. Cold Spring Harbor Laboratory, Cold Spring Harbor, NY.

Santa Cruz, S., and Baulcombe, D. C. 1993. Molecular analysis of potato virus $\mathrm{X}$ isolates in relation to the potato hypersensitivity gene $N x$. Mol. Plant-Microbe Interact. 6:707-714.

Schmitz, I., and Rao, A. L. N. 1996. Molecular studies on bromovirus capsid protein. I. Characterization of cell-to-cell movement-defective RNA 3 variants of brome mosaic virus. Virology 226:281-293.

Shintaku, M., and Palukaitis, P. 1990. Genetic mapping of cucumber mosaic virus. Pages 156-164 in: Viral Genes and Plant Pathogenesis. T. P. Pirone and J. G. Shaw, eds. Springer-Verlag, New York.

Shintaku, M. H., Zhang, L., and Palukaitis, P. 1992. A single amino acid substitution in the coat protein of cucumber mosaic virus induces chlorosis in tobacco. Plant Cell 4:751-757.

Shurtleff, M. C. 1980. Compendium of Corn Diseases. 2nd ed. American Phytopathological Society, St. Paul, MN.

Suzuki, M., Kuwata, S., Kataoka, J., Masuta, C., Nitta, N., and Takanami, Y. 1991. Functional analysis of deletion mutants of cucumber mosaic virus RNA 3 using an in vitro transcription system. Virology 183:106-113.

Suzuki, M., Kuwata, S., Masuta, C., and Takanami, Y. 1995. Point mutations in the coat protein of cucumber mosaic virus affect symptom expression and virion accumulation in tobacco. J. Gen. Virol. 76: 1791-1799.

Taliansky, M. E., and García-Arenal, F. 1995. Role of cucumovirus capsid protein in long-distance movement within the infected plant. J. Virol. 69:916-922.

Traynor, P., Young, B. M., and Ahlquist, P. 1991. Deletion analysis of brome mosaic virus 2a protein: Effects on RNA replication and systemic spread. J. Virol. 6:2807-2815.

Wahyuni, W. S., Dietzgen, R. G., Hanada, K., and Francki, R. I. B. 1992 Serological and biological variation between and within subgroup I and II strains of cucumber mosaic virus. Plant Pathol. 41:282-297.

Waterworth, H. E., Kaper, J. M., and Tousignant, M. E. 1979. CARNA 5 , the small cucumber mosaic virus-dependent replicating RNA, regulates disease expression. Science 204:845-847.

Weber, H., Schultze, S., and Pfitzner, A. J. P. 1993. Two amino acid substitutions in the tomato mosaic virus 30-kilodalton movement protein confer the ability to overcome the $\mathrm{Tm}-2^{2}$ resistance gene in tomato. J. Virol. 67:6432-6438.

Wellink, J., and van Kammen, A. 1989. Cell-to-cell transport of cowpea mosaic virus requires both the $58 \mathrm{~K} / 48 \mathrm{~K}$ proteins and the capsid proteins. J. Gen. Virol. 70:2279-2286.

Wikoff, W. R., Chao, J. T., Wang, G., Baker, T. S., and Johnson, J. E. 1997. The structure of cucumber mosaic virus: Cryoelectron microscopy, X-ray crystallography, and sequence analysis. Virology 232:9197.

Zhang, L., Hanada, K., and Palukaitis, P. 1994. Mapping local and systemic symptom determinants of cucumber mosaic cucumovirus in tobacco. J. Gen. Virol. 75:3185-3191.

Zhang, L., and Palukaitis, P. 1993. Sequences in LS-CMV controlling infection of maize map to the $5^{\prime}$ half of RNA 3. Phytopathology 83: 1349 